\title{
EXECUÇÃO CIVIL EXTRAJUDICIAL BRASILEIRA EM PERSPECTIVA: DA EXPERIÊNCIA EUROPEIA A ALGUMAS REFLEXÕES SOBRE O PROJETO DE LEI No. 6.204/20191
}

BRAZILIAN EXTRAJUDICIAL CIVIL ENFORCEMENT IN PERSPECTIVE: FROM THE EUROPEAN EXPERIENCE TO SOME REFLECTIONS ON THE BILL $N^{o}$. $6,204 / 2019$

José Henrique Mouta Pós-doutor (Faculdade de Direito da Universidade de Lisboa), doutor e mestre (Universidade Federal do Pará), Professor do Centro Universitário do Estado do Pará (CESUPA) e do Instituto Brasileiro de Ensino, Desenvolvimento e Pesquisa (IDP), procurador do estado do Pará e advogado. Belém/PA. www.henriquemouta.com.br Email: henriquemouta@uol.com.br

Marcelo Veiga Franco ${ }^{2}$ Doutor e Mestre em Direito pela Universidade Federal de Minas Gerais (UFMG). Visiting Scholar na University of Wisconsin-Madison. Professor de Direito Processual Civil na Faculdade Milton Campos. Procurador do Município de Belo Horizonte/MG. Advogado. Diretor Científico do Instituto de Direito Processual (IDPro). Belo Horizonte/MG. E-mail: veigafranco@ hotmail.com.

RESUMO: O artigo tem como objetivo apresentar um estudo da execução civil extrajudicial - também conhecida como desjudicialização da execução civil -, a qual é considerada um dos temas em voga do direito processual civil contemporâneo. Partindo da

\footnotetext{
${ }^{1}$ Artigo recebido em 02/08/2021 e aprovado em 16/11/2021.

${ }^{2} \mathrm{O}$ autor agradece ao Prof. Tiago Augusto Leite Retes pela interlocução acerca das ideias presentes no texto.
} 
afirmação da tutela executiva efetiva e eficiente como direito fundamental, examina-se as experiências de alguns países europeus, notadamente Suécia, Finlândia, Portugal, França, Espanha, Itália e Alemanha. Após, passa-se à análise do Projeto de Lei no . 6.204/2019, em tramitação no Congresso Nacional brasileiro, buscando-se responder à indagação se a proposição legislativa significa uma importação do sistema executivo português. Ao final, apresenta-se reflexões e considerações ao citado projeto de lei, com o intuito de contribuir com o amadurecimento do debate acerca da necessidade de desenvolvimento de um Sistema Multiportas de Execução. O estudo é realizado com base na vertente metodológica jurídico-dogmática, a partir da análise de elementos internos aos ordenamentos jurídicos de diversos países, e mediante o emprego dos tipos de investigação jurídico-comparativo e jurídico-prospectivo.

PALAVRAS-CHAVE: Execução civil extrajudicial; Execução na Europa; Projeto de Lei $n^{\circ} .6 .204 / 2019$.

ABSTRACT: The article aims to present a study of extrajudicial civil enforcement, which is considered one of the topics in vogue in contemporary civil procedural law. Starting from the affirmation of effective and efficient civil enforcement as a fundamental right, the experiences of some European countries are examined, notably Sweden, Finland, Portugal, France, Spain, Italy, and Germany. Afterwards, it is performed an analysis of Bill no. 6,204/2019, in progress at the Brazilian National Congress, seeking to answer the question whether the legislative proposal means an importation from the Portuguese enforcement system. At the end, reflections and considerations to the Bill are presented, in order to contribute to the maturing of the debate on the need to develop a Multi-Door Enforcement System. The study is carried out based on the legal-dogmatic methodological approach, from the analysis of internal elements to the legal systems of different countries, and it is used the types of legal-comparative and legal-prospective investigation.

KEYWORDS: Extrajudicial civil enforcement; Enforcement in Europe; Bill no. 6,204 / 2019. 


\section{INTRODUÇÃO}

O tema da execução civil extrajudicial - comumente referido também como desjudicialização da execução civil - vem ganhando expressivo destaque no atual cenário jurídico brasileiro. Em apertada síntese, trata-se de examinar os limites e as possibilidades não apenas do processamento e tramitação de procedimentos executivos fora da instância judicial, como também do emprego de técnicas e medidas extrajudiciais que visam ao cumprimento forçado de dívidas e obrigações ou à constrição patrimonial.

As pesquisas e artigos científicos sobre a matéria são cada vez mais frequentes. Igualmente, é possível verificar a ocorrência de diversos eventos acadêmicos realizados em ambientes virtuais que visam ao debate acerca de questões polêmicas e controversas.

Recentemente, a temática ganhou dois capítulos importantes na seara jurisprudencial. Em acórdão publicado no dia 11/03/2021, o Superior Tribunal de Justiça (STJ), ao julgar o recurso especial (REsp) $n^{\circ}$. 1.807.923/SC (Tema Repetitivo 1026), fixou tese jurídica no sentido de que "O art. $782, \S 3^{\circ}$ do $\mathrm{CPC}$ é aplicável às execuções fiscais, devendo o magistrado deferir o requerimento de inclusão do nome do executado em cadastros de inadimplentes, preferencialmente pelo sistema SERASAJUD, independentemente do esgotamento prévio de outras medidas executivas, salvo se vislumbrar alguma dúvida razoável à existência do direito ao crédito previsto na Certidão de Dívida Ativa - CDA”.

Embora se refira às execuções fiscais, a decisão é relevante ao destacar que a inserção em cadastros de inadimplência e restrição de créditos - ou seja, ato de natureza executiva praticado no âmbito extrajudicial - "é medida coercitiva que promove no subsistema os valores da efetividade da execução, da economicidade, da razoável duração do processo e da menor onerosidade para o devedor (arts. $4^{\circ}, 6^{\circ}, 139$, inc. IV, e 805 do CPC)". O STJ ressaltou ainda que a inclusão do nome do executado em cadastros de inadimplentes pode ocorrer "sem interferência ou necessidade de autorização do magistrado", a fim de permitir "uma maior perspectiva de sucesso" na arrecadação fiscal 
ante a desnecessidade de ajuizamento de execuções fiscais "que abarrotarão as prateleiras (físicas ou virtuais) do Judiciário, com baixo percentual de êxito". 3

Posteriormente, o Supremo Tribunal Federal (STF), em sessão virtual do Tribunal Pleno de 08/04/2021 (ata de julgamento publicada em 14/04/2021), concluiu o julgamento do recurso extraordinário (RE) $n^{\circ}$. 627.106/PR e fixou a tese de que "É constitucional, pois foi devidamente recepcionado pela Constituição Federal de 1988, o procedimento de execução extrajudicial, previsto no Decreto-lei $n^{\circ}$ 70/66". ${ }^{4}$ Dito de outo modo, o STF declarou a constitucionalidade da execução extrajudicial de dívidas hipotecárias, sinalizando uma maior abertura para o emprego de medidas executivas de obrigações e créditos inadimplidos sem a intervenção direta do Poder Judiciário.

No campo legislativo, há projetos de lei em tramitação no Congresso Nacional que visam a uma reformulação do procedimento executivo ou do emprego de técnicas de cobrança e satisfação de obrigações constantes de títulos executivos judiciais e extrajudiciais. O Projeto de Lei nº . 6.204/2019, de autoria da Senadora Soraya Thronicke objeto de ponderações nesse artigo - é um deles.

Diante dessa breve contextualização, percebe-se a importância de refletir e debater sobre pontos sensíveis da citada proposição legislativa. Ao que parece, o sistema jurídico brasileiro caminha em direção a uma ampliação das possibilidades de práticas executivas na esfera extrajudicial - tal qual já ocorre em vários países europeus -, o que torna necessário o amadurecimento das discussões sobre o assunto. ${ }^{5}$

\section{A TUTELA EXECUTIVA EFETIVA E EFICIENTE COMO DIREITO FUNDAMENTAL}

\footnotetext{
${ }^{3}$ BRASIL. SUPERIOR TRIBUNAL DE JUSTIÇA. RECURSO ESPECIAL: RESP 1.807.923/SC, Relator Ministro Og Fernandes, Primeira Seção, julgado em 24/02/2021, DJe 11/03/2021.

4 BRASIL. SUPREMO TRIBUNAL FEDERAL. RECURSO EXTRAORDINÁRIO: RE 627.106/PR, Relator Ministro Dias Toffoli, Tribunal Pleno, julgado em 08/04/2021, extrato da ata de julgamento DJe $14 / 04 / 2021$

${ }^{5} \mathrm{O}$ texto tem o objetivo de discutir e refletir acerca da proposta legislativa pertinente à execução civil. Sobre a temática da desjudicialização da execução fiscal e a análise do PL nº. 4.257/2019, conferir: MOUTA, José Henrique; FRANCO, Marcelo Veiga. A desjudicialização da execução fiscal: reflexões sobre o PL $\mathrm{n}^{\circ}$ 4.257/2019. Disponível em: https://www.conjur.com.br/2021-abr-09/araujo-franco-reflexoes-projeto-lei42572019. Acesso em: 26 abr. 2021.
} 
A qualificação do devido processo legal com as características da efetividade e da eficiência é uma tendência mundial. ${ }^{6}$

Como exemplo, o International Institute for the Unification of Private Law (UNIDROIT), em parceria com o American Law Institute (ALI), incluem a efetiva adjudicação (effective adjudication) e a eficiente resolução do processo (efficient resolution of the proceeding) dentro do conjunto de princípios do processo civil transnacional (principles of transnational civil procedure).

No artigo 11.2, está previsto que as partes compartilham com o tribunal a responsabilidade de promover a resolução do processo justa, eficiente e em razoável duração. Já o artigo 14.1 atribui às cortes judiciárias a responsabilidade de direção e gerenciamento do processo com o fim de se alcançar a solução do conflito justa, eficiente e em prazo razoável.

Especificamente no que se refere à atividade executiva, o artigo 29 dispõe que os procedimentos devem estar disponíveis para a execução célere e efetiva das decisões. Nos comentários sobre esse artigo, o ALI/UNIDROIT destaca que muitos sistemas jurídicos possuem procedimentos arcaicos e ineficientes para o cumprimento das sentenças, embora, do ponto de vista do litigante exitoso, a execução efetiva da decisão é um elemento essencial de justiça. ${ }^{7}$

Nessa perspectiva, é possível afirmar que a efetividade e a eficiência processuais abrangendo a atividade satisfativa - são componentes da concepção contemporânea do devido processo legal e retratam escopos da função jurisdicional estatal. A adequada prestação da tutela executiva consiste em direito fundamental daquele que busca o adimplemento de obrigação da qual é o legítimo titular.

\footnotetext{
${ }^{6}$ Efetividade e eficiência processuais são conceitos que não se confundem. Processo efetivo é aquele capaz de proporcionar a integral satisfação do direito material, inclusive mediante o reconhecimento da tutela executiva como direito fundamental, dentro de uma concepção mais ampla do princípio da inafastabilidade da jurisdição estatal. Por sua vez, processo eficiente é aquele no qual o órgão judicial viabiliza uma alocação apropriada dos recursos - materiais, humanos, temporal etc. - para se alcançar a finalidade do processo; o juiz, ao exercer a sua função de gestão processual, emprega satisfatoriamente os meios para se alcançar os fins do processo, em termos simultaneamente qualitativos, quantitativos e probabilísticos (DIDIER JR., Fredie. Curso de Direito Processual Civil: Introdução ao Direito Processual Civil, Parte Geral e Processo do Conhecimento. Salvador: JusPodivm, 2019, p. 128-134 e 144-145).

${ }^{7}$ INTERNATIONAL INSTITUTE FOR THE UNIFICATION OF PRIVATE LAW - UNIDROIT. ALI / UNIDROIT Principles of Transnational Civil Procedure. 13 out. 2020. Disponível em: https://www.unidroit.org/instruments/civil-procedure/ali-unidroit-principles. Acesso em: 16 mar. 2021.
} 
O nosso Código de Processo Civil (CPC) caminha no mesmo sentido e inclui a efetividade da atividade satisfativa como uma das normas fundamentais do processo civil brasileiro. Ao mesmo tempo em que assegura o direito de obtenção da solução integral do conflito em prazo razoável - incluída a fase executiva (art. $4^{\circ}$ do CPC) -, a legislação processual impõe o dever de cooperação recíproca de todos os sujeitos processuais para que se alcance decisão de mérito justa e efetiva (art. $6^{\circ}$ do CPC).

Entretanto, é preciso pontuar. No ambiente de constitucionalização do processo (art. $1^{\circ}$ do CPC), a busca pela efetividade e eficiência processuais não está permitida a todo custo, uma vez que deve vir acompanhada da observância inarredável das normas constitucionais. A noção de processo efetivo e eficiente não autoriza o sacrifício imoderado de direitos individuais e de outras garantias fundamentais que compõem o devido processo legal.

Ainda que na esfera extrajudicial, o devido processo legal não pode importar em "retrocesso garantístico". O amplo contexto de desjudicialização de controvérsias no Brasil - inclusive do emprego de medidas executivas - não pode importar em déficit de proteção de garantias fundamentais do processo, as quais "representam conquistas inegociáveis da ciência processual". 8

A razoabilidade da duração do processo (art. $5^{\circ}$, LXXVIII, da CRFB), a eficiência da prestação jurisdicional estatal (art. 37, caput, da CRFB) e a concretização do direito material não são objetivos excludentes. Pelo contrário, processo devido (art. $5^{\circ}$, LIV, da CRFB) é aquele que, simultaneamente, proporciona em prazo razoável o exercício de garantias fundamentais e a efetivação adequada do direito material perseguido em juízo.

\section{AS EXPERIÊNCIAS DE ALGUNS PAÍSES EUROPEUS QUANTO À EXECUÇÃO CIVIL}

O reconhecimento da tutela executiva efetiva e eficiente como direito fundamental impõe ao sistema jurídico a função de viabilizar e promover o emprego adequado de atos executivos necessários ao cumprimento de obrigações. É claro que, nesse cenário, a adoção

\footnotetext{
${ }^{8}$ HILL, Flávia Pereira. Desjudicialização e acesso à justiça além dos tribunais: pela concepção de um devido processo legal extrajudicial. Revista Eletrônica de Direito Processual - REDP, ano 15, v. 22, n. 1, p. 379408, Rio de Janeiro, jan./abr. 2021.
} 
de técnicas e medidas executivas se submete a limites e instrumentos de fiscalização, a fim de evitar abusos e excessos em detrimento da dignidade humana da pessoa do devedor (art. $8^{\circ}$ do CPC). ${ }^{9}$

No Brasil, a busca pela efetividade da execução atribui ao órgão judicial a incumbência de determinar todas as medidas executivas necessárias para assegurar a satisfação de direitos e o cumprimento de ordens judiciais (art. 782 do CPC), ainda que não previstas em lei (atípicas) e na esfera extrajudicial (art. 139, IV, do CPC). Para tanto, o juiz está sujeito a balizas e mecanismos de controle, competindo-lhe observar o princípio da menor onerosidade ao devedor (art. 805 do CPC).

$\mathrm{Na}$ hipótese de adoção de medidas executivas atípicas, exige-se ainda o respeito ao contraditório substancial (arts. $7^{\circ}, 9^{\circ}$ e 10 do CPC), à fundamentação adequada da decisão judicial (art. 489, $\S 1^{\circ}$, do CPC), ao caráter de subsidiariedade do ato executivo não previsto em lei, ao postulado da proporcionalidade e à existência de indícios de patrimônio expropriável do devedor (art. 789 do CPC). ${ }^{10}$

Todavia, na experiência do direito comparado, a utilização de técnicas e medidas executivas para o fim de assegurar o adimplemento obrigacional não se limita ao ambiente da jurisdição estatal. É possível perceber que, na Europa, há uma variedade de sistemas jurídicos que tratam de forma diferente o procedimento executivo: em alguns casos, as técnicas executivas são empregadas em fóruns completamente alheios ao Poder Judiciário; em outros casos, há um compartilhamento entre as instâncias judicial e extrajudicial; e, finalmente, há situações em que o processo de execução e o emprego de medidas executivas se insere totalmente dentro da estrutura judiciária.

A seguir, passa-se ao estudo das experiências de alguns países europeus quanto à execução civil:

\footnotetext{
${ }^{9}$ É de longa data a evolução jurídica no sentido de atribuir ao patrimônio do devedor, e não à sua pessoa, a responsabilidade pelo recaimento de dívidas e obrigações (art. 789 do CPC). Nesse particular, é importante mencionar, como marcos históricos, a Lex Poetelia Papiria, do ano 326 a.C., que aboliu a possibilidade de escravidão do devedor como forma de garantia da obrigação; e a pignoris capio ("ação por tomada de penhor"), do direito romano, que instituiu a possibilidade de o credor tomar parcela dos bens pertencentes ao devedor a fim de assegurar o adimplemento do débito (NÓBREGA, Guilherme Pupe da. Reflexões sobre a atipicidade das técnicas executivas e o artigo 139, IV, do CPC de 2015. Disponível em: https://www.migalhas.com.br/coluna/processo-e-procedimento/243746/reflexoes-sobre-a-atipicidade-dastecnicas-executivas-e-o-artigo-139--iv--do-cpc-de-2015. Acesso em: 19 abr. 2021).

${ }^{10}$ BRASIL. SUPERIOR TRIBUNAL DE JUSTIÇA. RECURSO ESPECIAL: RESP 1.782.418/RJ, Relatora Ministra Nancy Andrighi, Terceira Turma, julgado em 23/04/2019, DJe 26/04/2019.
} 


\subsection{Suécia}

Na Suécia, a execução é processada e realizada pelo Serviço Sueco de Execução (Kronofogdemyndigheten), que é órgão sob supervisão do Ministério das Finanças e pertencente ao Poder Executivo. ${ }^{11}$ Trata-se de instância administrativa estranha ao Poder Judiciário, que é composta por oficiais não-judiciários (Kronofogden) que possuem a competência para decidir sobre a penhora de bens, realizar investigação sobre o patrimônio do devedor, intimar o executado para fornecer informações sobre seus bens, aplicar multa no caso de ocultação patrimonial, e expedir vereditos e ordens de pagamento de dívidas e cumprimento de obrigações.

A partir do momento em que se forma o título executivo, torna-se desnecessária qualquer decisão judicial para que a sua execução seja iniciada. ${ }^{12} \mathrm{O}$ descumprimento de uma injunção com ordem de pagamento (injunction for order to pay) expedida pelo Kronofogdemyndigheten resulta em um veredito (veredict) para pagamento de dívida ou cumprimento de obrigação de fazer ou não fazer, o qual ostenta força jurídica análoga a uma decisão judicial (court ruling).

Isso quer dizer que o executado é obrigado a pagar ou executar imediatamente a ação constante do veredito. Caso o devedor persista inadimplente, a própria autoridade administrativa (Kronofogden) poderá adotar atos executivos como a penhora e apreensão de bens, como também medidas expropriatórias como a alienação do patrimônio do devedor. Para tanto, não há necessidade de qualquer intervenção do Poder Judiciário. ${ }^{13}$

\subsection{Finlândia}

\footnotetext{
${ }^{11}$ VAN RHEE, Cornelis Hendrik, UZELAC, Alan. Enforcement and Enforceability - Tradition and Reform. Intersentia: Cambridge, 2010, p. 48; JACOBSSON. Enforcement proceedings in Sweden. RHDI 50, 1997, p. 483 et seq.

12 EUROPEAN JUSTICE. Procedures for enforcing a judgment - Sweden. Disponível em: https://ejustice.europa.eu/content_procedures_for_enforcing_a_judgment-52-se-en.do?member=1. Acesso em: 17 mar. 2021.

13 KRONOFOGDEN. Veredict for an order to pay. Disponível em: https://www.kronofogden.se/enGB/Utslag.html. Acesso em: 17 mar. 2021.
} 
$\mathrm{Na}$ Finlândia, também a execução é conduzida por órgão administrativo completamente desvinculado do Poder Judiciário. ${ }^{14}$ Há autoridades locais de execução (local enforcement authorities) - v.g., Autoridade de Execução de Helsinque (Helsingin ulosottovirasto) - cuja competência para apresentação do título executivo é determinada com base no local de residência do devedor. Embora as solicitações de cobrança sejam feitas às autoridades administrativas locais, cabe a elas a prática de atos executivos em todo o país.

Quando o processo executivo é deflagrado, o devedor recebe uma notificação (notice of filing) e uma demanda de pagamento (demand for payment). Caso o devedor persista inadimplente, a autoridade administrativa procederá à investigação patrimonial e apuração dos rendimentos e bens do devedor constantes de dados cadastrais.

Aos agentes executivos locais é permitida a realização de consultas bancárias e acesso a informações sobre a situação financeira e patrimonial do executado. Outrossim, cabe a eles apreender todos os tipos de bens e direitos móveis e imóveis pertencentes ao devedor, assim como proceder às suas alienação e liquidação. Os credores podem ainda solicitar às autoridades locais de execução o monitoramento de uma dívida por um período de até dois anos, por meio do chamado registro passivo (passive registration), caso não seja possível cobrar a dívida imediatamente.

Todo o processamento e tramitação da execução ocorre sem a intervenção do Poder Judiciário. Ademais, é dispensável a presença do advogado para que o credor possa iniciar o procedimento administrativo de execução. ${ }^{15}$

\subsection{Portugal}

Em Portugal, houve ampla reforma do processo executivo a partir dos Decreto-Lei $n^{\circ}$. 38/2003, Decreto-Lei no . 226/2008, Lei n. ${ }^{\circ}$ 41/2013 (CPC português) e Lei n. ${ }^{\circ}$ 32/2014. De um lado, institucionalizou-se a categoria do agente de execução, profissional liberal de natureza privada e com formação jurídica, cuja função é praticar medidas executivas sob a

\footnotetext{
${ }^{14}$ VAN RHEE, Cornelis Hendrik, UZELAC, Alan. Enforcement and Enforceability - Tradition and Reform. Intersentia: Cambridge, 2010, p. 48; KOULU. Enforcement in Finland. RHDI 50, 1997, p. 537 et seq.

${ }^{15}$ EUROPEAN JUSTICE. Procedures for enforcing a judgment - Finland. Disponível em: https://ejustice.europa.eu/content_procedures_for_enforcing_a_judgment-52-fi-en.do?member=1. Acesso em: 19 abr. 2021.
} 
supervisão de juízes. De outro lado, criou-se o procedimento extrajudicial pré-executivo (PEPEX), com o objetivo de retirar dos juízes a incumbência de realizar tarefas burocráticas de natureza executiva. ${ }^{16}$

De modo geral, o processo judicial de execução é deflagrado perante o Poder Judiciário, mediante a apresentação do requerimento executivo. Ao juiz compete o controle da validade do procedimento executivo e o exercício da atividade cognitiva, por meio do julgamento da oposição à execução e à penhora, bem como das reclamações e impugnações apresentadas em face de atos praticados pelos agentes de execução. ${ }^{17}$

Por seu turno, os agentes de execução atuam como auxiliares do juízo, cabendolhes a prática de diversas medidas executivas, tais como: consultas aos registros informáticos e às bases eletrônicas de dados referentes ao patrimônio penhorável do devedor (art. 748..$^{\circ}$ do CPC português); citação, intimação e notificação do executado, inclusive para indicar bens à penhora (v.g., arts. $231 .^{\circ}$ e $750 .^{\circ}$ do CPC português); realização de penhora, registros e respectiva notificação do executado (art. $753 .^{\circ}$ do CPC português); liquidações e pagamentos (art. 719.1. ${ }^{\circ}$ do CPC português).

Portanto, verifica-se uma repartição de competências executivas entre o tribunal e o agente de execução. Segundo o art. 719.1. ' do CPC português, ao agente de execução cabe "efetuar todas as diligências do processo executivo que não estejam atribuídas à secretaria ou sejam da competência do juiz". Ademais, mesmo após a extinção da instância, a ele compete "assegurar a realização dos atos emergentes do processo que careçam da sua intervenção" (art. 719.2. ' do CPC português).

Ademais, a secretaria do juízo também participa desse compartilhamento de atos executivos, mediante, por exemplo, a notificação oficiosa do agente de execução acerca "da pendência de procedimentos ou incidentes de natureza declarativa deduzidos na execução e dos atos aí praticados que possam ter influência na instância executiva" (art. 719.4. ${ }^{\circ}$ do CPC português).

\footnotetext{
${ }^{16}$ RODRIGUES, Marco Antonio; RANGEL, Rafael Calmon. O procedimento extrajudicial pré-executivo lusitano (PEPEX): algumas lições para o sistema brasileiro. Revista de Processo, v. 282, São Paulo, p. 455471, ago. 2018.

${ }^{17}$ EUROPEAN JUSTICE. Procedures for enforcing a judgment - Portugal. Disponível em: https://ehttps://e-justice.europa.eu/content_procedures_for_enforcing_a_judgment-52-pt-en.do?member=1. Acesso em: 21 abr. 2021.
} 
Além do processo judicial de execução, a legislação portuguesa também prevê a possibilidade de um procedimento extrajudicial pré-executivo (PEPEX). Trata-se de procedimento de natureza facultativa, que tramita em meio eletrônico, e considerado mais célere e econômico em comparação com o processo judicial de execução. Geralmente, o credor obtém em poucos dias as informações pertinentes à real possibilidade de recuperação do seu crédito ou a certificação da ausência de bens penhoráveis do devedor, sem que seja necessário provocar a atividade judicial. ${ }^{18}$

O PEPEX se destina, dentre outras finalidades, "à identificação de bens penhoráveis através da disponibilização de informação e consulta às bases de dados de acesso direto eletrónico previstas no Código de Processo Civil, aprovado pela Lei n. ${ }^{\circ}$ 41/2013, de 26 de junho, para os processos de execução cuja disponibilização ou consulta não dependa de prévio despacho judicial" (art. $2^{\circ}$ da Lei $n^{\circ}$. 32/2014). Os atos de penhora e apreensão de bens não são cabíveis no âmbito do PEPEX, uma vez que, para tanto, é necessária a sua convolação em processo judicial de execução.

Segundo o art. $3^{\circ}$ da Lei $n^{\circ}$. 32/2014, a escolha pelo credor do PEPEX é admissível desde que preenchidos os seguintes requisitos: “a) O requerente esteja munido de título executivo que reúna as condições para aplicação da forma sumária do processo comum de execução para pagamento de quantia certa, nos termos do artigo $550 .^{\circ}$ do Código de Processo Civil; b) A dívida seja certa, exigível e líquida; c) O requerente indique o seu número de identificação fiscal em Portugal, bem como o do requerido".

No curso do procedimento, cabe ao agente de execução efetuar "as consultas às bases de dados da administração tributária, da segurança social, do registo civil, do registo nacional de pessoas coletivas, do registo predial, do registo comercial e do registo de veículos e de outros registos ou arquivos semelhantes, para obtenção de informação referente à identificação e localização do requerido, bem como dos bens penhoráveis de que seja titular" (art. $9^{\circ}$ da Lei nº 32/2014). As consultas são realizadas pelo agente de execução por meio de plataforma eletrônica ("registro informático de execuções"), denominada de SISAAE.

\footnotetext{
${ }^{18}$ EUROPEAN JUSTICE. Procedures for enforcing a judgment - Portugal. Disponível em: https://ehttps://e-justice.europa.eu/content_procedures_for_enforcing_a_judgment-52-pt-en.do?member=1. Acesso em: 21 abr. 2021.
} 
Conforme o art. 10 da Lei $n^{\circ}$. 32/2014, cabe ao agente de execução, após a concretização das consultas, elaborar "um relatório que resume o resultado das mesmas, indicando quais os bens identificados ou a circunstância de não terem sido identificados bens penhoráveis". Ao credor, no prazo de 30 dias após a notificação do relatório, cabe requerer, sob pena de extinção do procedimento: “a) A convolação do procedimento extrajudicial pré-executivo em processo de execução"; ou "b) No caso de não terem sido identificados bens suscetíveis de penhora, a notificação do requerido" para "a) Pagar o valor em dívida, acrescido dos juros vencidos até à data limite de pagamento e dos impostos a que possa haver lugar, bem como dos honorários devidos ao agente de execução"; "b) Celebrar acordo de pagamento com o requerente"; "c) Indicar bens penhoráveis”; “d) Opor-se ao procedimento” (arts. 11 e 12 da Lei no. 32/2014).

Ademais, de acordo com o art. 27 da Lei no. 32/2014, é cabível a apresentação por qualquer interessado de reclamação em face dos atos praticados pelo agente de execução no âmbito do PEPEX, no prazo de 30 dias, dirigida aos órgãos de fiscalização e disciplina da atividade dos agentes de execução. Por seu turno, também é possível o oferecimento de impugnação contra os atos dos órgãos de fiscalização e disciplina da atividade dos agentes de execução perante os tribunais administrativos.

Caso a irresignação se dê quanto à legalidade dos atos praticados pelo agente de execução, a reclamação deve ser dirigida aos tribunais judiciais com competência em matéria de execução de natureza cível. ${ }^{19}$

Enfim, o escopo precípuo do PEPEX é a obtenção, na esfera extrajudicial, do pagamento voluntário do débito ou a celebração de acordo entre credor e devedor. A intervenção judicial ocorre apenas quando há a convolação do PEPEX em processo judicial de execução na hipótese de ausência de quitação espontânea, ou na hipótese em que o requerido apresenta oposição ao procedimento.

\subsection{França}

19 REPÚBLICA PORTUGUESA. Lei $n^{o}$. 32/2014. Disponível em: https://dre.pt/pesquisa//search/25345939/details/maximized. Acesso em: 21 abr. 2021. 
Na França, os huissiers de justice são agentes públicos (public legal officials), licenciados e designados pelo Ministério da Justiça, que detêm o monopólio para a prática de atos de execução compulsória de decisões judiciais e títulos executivos. ${ }^{20}$ Trata-se de funcionário público ministerial (officier public ministériel) que atua como delegatário do Estado para a consecução de prerrogativas de poder público (prérogatives de puissance publique). ${ }^{21}$ Embora exerçam atribuições de natureza pública e dependam de licença ministerial concedida pelo Estado, os huissiers de justice são considerados como uma profissão liberal regulamentada (profession libérale réglementée) ${ }^{22}$ inserida ambiente privado de livre concorrência.

Os huissiers de justice são profissionais que percebem remuneração específica para a prestação dos seus serviços. $\mathrm{O}$ valor para custeio das medidas coercitivas é geralmente adiantado pelo credor, com posterior reembolso pelo devedor. A fim de manter as taxas padronizadas de execução em um nível baixo, os huissiers de justice possuem margem de liberdade para negociar taxas com seus clientes por atividades não diretamente relacionadas à execução, ou nos casos em que estejam presentes dificuldades especiais previstas na legislação. ${ }^{23}$

A forma de pagamento dos emolumentos (émoluments) e respectivos valores dos atos executivos constam de regulamento próprio. O montante a ser pago aos huissiers de justice é variável de acordo com os tipos de atos executivos praticados, o valor de avaliação do patrimônio envolvido, ou até mesmo o profissional escolhido. É possível isenção ou redução do pagamento da remuneração em algumas hipóteses, como nos casos de assistência judiciária.

As funções dos huissiers de justice abrangem, dentre outras, a execução de decisões judiciais (exécution d'une décision de justice), a proposição de acordos (proposer des arrangements amiables), a emissão de instrumentos autênticos (délivrance d'actes

20 EUROPEAN JUSTICE. Procedures for enforcing a judgment - France. Disponível em: https://ejustice.europa.eu/content_procedures_for_enforcing_a_judgment-52-fr-en.do?member=1. Acesso em: 20 abr. 2021.

21 RÉPUBLIQUE FRANÇAISE. Huissier de justice. Disponível em: https://www.servicepublic.fr/particuliers/vosdroits/F2158. Acesso em: 20 abr. 2021; RÉPUBLIQUE FRANÇAISE. Officier public ministériel. Disponível em: https://www.service-public.fr/particuliers/glossaire/R53971. Acesso em: 20 abr. 2021.

22 COMMISSAIRES DE JUSTICE - CHAMBRE NATIONALE. Les missions de l'huissier de justice. Disponível em: https://www.huissier-justice.fr/nos-missions/. Acesso em: 22 abr. 2021.

${ }^{23}$ KENNETT, Wendy. The enforcement of judgments in Europe. Oxford: Oxford, 2000, p. 76-77. 
authentiques) contendo a descrição e relatório de fatos, e a entrega de citações, intimações e documentos legais.

As medidas executivas praticadas pelos huissiers de justice são passíveis de contestação judicial. Se o ato estiver diretamente relacionado a um processo judicial em curso, a impugnação deve ser dirigida ao tribunal responsável pelo caso. Caso contrário, a impugnação deve ser encaminhada ao juízo de execução (juge de l'exécution). ${ }^{24}$

\subsection{Espanha}

Na Espanha, o art. 117.3 da Constituição Espanhola atribui competência exclusiva aos juízes e tribunais para o exercício do poder jurisdicional (potestad jurisdiccional), para os fins de julgamento de processos e execução do julgado. ${ }^{25}$

Por seu turno, a Ley de Enjuiciamiento Civil, em seu título III, ao tratar da execução (ejecución), prevê nos arts. 545.1 e 551.1 a competência do juízo de primeira instância para emitir a determinação judicial contendo a ordem geral de execução (orden general de ejecución). Para tanto, uma vez apresentada a demanda executiva, cabe ao magistrado avaliar a presença dos requisitos e pressupostos processuais, aferir a regularidade formal do título executivo e verificar se os atos de execução solicitados estão em conformidade com a natureza e o conteúdo do título. ${ }^{26}$

Após a expedição da orden general de ejecución pelo magistrado, cabe ao Letrado de la Administración de Justicia - anteriormente denominado de Secretario Judicial expedir decreto (decreto) contendo as medidas executivas concretas que serão adotadas.

Os Letrados de la Administración de Justicia são funcionários públicos que constituem um Corpo Jurídico Superior (Cuerpo Superior Jurídico), de caráter único e nacional, que atuam a serviço da administração da justiça e com vínculo de dependência ao

\footnotetext{
24 RÉPUBLIQUE FRANÇAISE. Huissier de justice. Disponível em: https://www.servicepublic.fr/particuliers/vosdroits/F2158. Acesso em: 20 abr. 2021.

${ }_{25}$ GOBIERNO DE ESPAÑA. Constitución Española. Disponível em: https://www.boe.es/buscar/act.php?id=BOE-A-1978-31229. Acesso em: 20 abr. 2021.

26 GOBIERNO DE ESPAÑA. Ley 1/2000, de 7 de enero, de Enjuiciamiento Civil. Disponível em: https://www.boe.es/buscar/act.php?id=BOE-A-2000-323. Acesso em: 20 abr. 2021.
} 
Ministério da Justiça. Eles exercem suas funções com caráter de autoridade, na medida em que exercem a direção da secretaria judicial (Oficina Judicial). ${ }^{27}$

De modo geral, o Letrado de la Administración de Justicia controla o procedimento de execução e adota os atos executivos pertinentes, tais como emissão de requerimento de pagamento (requerimiento de pago), apreensão de bens do executado (embargo de bienes), medidas de localização e investigação de bens (medidas de localización y averiguación de los bienes) e realização de bloqueios em contas bancárias (art. 551.3 da Ley de Enjuiciamiento Civil). ${ }^{28}$

A orden general de ejecución expedida pelo juiz consiste em decisão irrecorrível, embora o executado possa apresentar oposição à execução (art. 551.4 da Ley de Enjuiciamiento Civil). Por seu turno, em face do decreto emitido pelo Letrado de la Administración de Justicia é cabível a interposição de recurso direto de revisão (recurso directo de revisión), sem efeito suspensivo, dirigido para o tribunal que proferiu a orden general de ejecución (art. 551.5 da Ley de Enjuiciamiento Civil). ${ }^{29}$

\subsection{Itália}

Na Itália, os tribunais ordinários (Tribunali ordinari) possuem a competência para ordenar o adimplemento compulsório de obrigação certa, líquida e exigível constante de título executivo (art. 474 do Codice di procedura civile). ${ }^{30} \mathrm{O}$ processo de execução (processo di esecuzione) é deflagrado por meio da expedição de uma intimação (precetto) dirigida ao devedor para o cumprimento da obrigação em prazo não inferior a dez dias,

27 GOBIERNO DE ESPAÑA. Letrados de la Administración de Justicia. Disponível em: https://www.mjusticia.gob.es/ca/ciudadanos/empleo-publico/acceso-convocatorias-perfiles/secretariosjudiciales. Acesso em: 21 abr. 2021.

28 GOBIERNO DE ESPAÑA. Ley 1/2000, de 7 de enero, de Enjuiciamiento Civil. Disponível em: https://www.boe.es/buscar/act.php?id=BOE-A-2000-323. Acesso em: 20 abr. 2021; EUROPEAN JUSTICE. Procedimientos de ejecución de una sentencia - España. Disponível em: https://ejustice.europa.eu/content_procedures_for_enforcing_a_judgment-52-es-es.do?member=1. Acesso em: 17 mar. 2021.

29 GOBIERNO DE ESPAÑA. Ley 1/2000, de 7 de enero, de Enjuiciamiento Civil. Disponível em: https://www.boe.es/buscar/act.php?id=BOE-A-2000-323. Acesso em: 20 abr. 2021.

30 EUROPEAN JUSTICE. Procedures for enforcing a judgment - Italy. Disponível em: https://ejustice.europa.eu/content_procedures_for_enforcing_a_judgment-52-it-en.do?member=1. Acesso em: 20 abr. 2021. 
com a advertência de que, no caso de inadimplemento, haverá execução forçada (esecuzione forzata) (art. 480 do Codice di procedura civile).

No sistema jurídico italiano, a prática dos atos executivos compete a agente público vinculado ao Ministério da Justiça. O oficial de justiça responsável pelo emprego das medidas executivas (ufficiale giudiziario), ao atuar como auxiliar da administração da justiça, exerce funções como executar ordens judiciais, cumprir citações, intimações e notificações (art. 59 do Codice di procedura civile), realizar atos de penhora (pignoramento) (art. 492 do Codice di procedura civile) e receber pagamento (art. 494 do Codice di procedura civile). O ufficiale giudiziario responde civilmente nos casos de dolo, culpa grave ou quando, sem justa causa, deixa de praticar ato que lhe é legalmente exigido (art. 60 do Codice di procedura civile). ${ }^{31}$

\subsection{Alemanha}

Na Alemanha, o poder de execução compulsória (Zwangsvollstreckung) é atribuído ao Estado. O procedimento executivo depende de autorização judicial do tribunal local (Amtsgericht) de residência do devedor. A penhora de bens, a execução de medidas coercitivas sobre o patrimônio do devedor (Zwangsmaßnahmen) e a alienação forçada de direitos (Zwangsversteigerung) estão condicionadas à ordem do juiz.

No sistema germânico, quando o procedimento executivo se refere a uma sentença judicial, "o processo é desjurisdicionalizado e o juiz só intervém em caso de litígio". Por outro lado, "quando a execução se baseia em outro título, o juiz exerce também uma função de controlo prévio, emitindo a fórmula executiva, sem a qual não é desencadeado o processo executivo". ${ }^{32}$

A prática dos atos executivos é incumbência de "funcionário judicial pago pelo erário público, ainda que os encargos decorrentes da sua intervenção sejam suportados, no final, pelo executado, quando lhe são encontrados bens, e excepcionalmente pelo

31 REPUBBLICA ITALIANA. Codice di procedura civile. Disponível em: https://www.altalex.com/documents/codici-altalex/2015/01/02/codice-di-procedura-civile. Acesso em: 20 abr. 2021.

${ }^{32}$ FREITAS, José Lebre de. Os paradigmas da acção executiva. In: A reforma da acção executiva - trabalhos preparatórios. v. I, Ministério da Justiça, Gabinete de Política Legislativa e Planejamento, Lisboa: 2001, p. 80 . 
exequente, no caso de execução injusta". ${ }^{33} \mathrm{O}$ oficial de justiça responsável pela condução das medidas executivas (Gerichtsvollzieher) atua sob a supervisão administrativa do juiz presidente do tribunal local. Todavia, a ele é assegurada independência funcional como órgão autônomo de execução, vale dizer, a ascendência administrativa do magistrado não pode interferir na prestação dos seus serviços voltados ao adimplemento de créditos e obrigações.

O Gerichtsvollzieher é responsável pela execução das sentenças em matéria cível de acordo com o Livro 8 do Código de Processo Civil Alemão (Zivilprozessordnung $Z P O$ ), o qual prevê dispositivos sobre a execução compulsória. $\mathrm{O}$ foco da sua atuação se concentra não apenas na investigação de bens, como também na responsabilidade de concluir o procedimento executivo de modo eficiente e efetivo. Com isso, ao oficial de justiça são concedidos poderes e competências para permitir o parcelamento de dívidas, receber declaração juramentada de bens, e executar ordens de despejo, penhora e mandados de prisão.

As medidas executivas adotadas pelo oficial de justiça no processo de execução podem ser judicialmente contestadas perante o juízo competente mediante a apresentação de uma objeção (Erinnerung). ${ }^{34}$

\section{CONSIDERAÇÕES, REFLEXÕES E PONDERAÇÕES SOBRE O PROJETO DE LEI No. 6.204/19: A PROPOSIÇÃO LEGISLATIVA SIGNIFICA UMA IMPORTAÇÃO DO SISTEMA EXECUTIVO PORTUGUÊS?}

A análise da experiência europeia demonstra a existência de diversas formas de tratamento do procedimento executivo: em alguns países, as técnicas executivas são integralmente empregadas em instâncias administrativas e sem a intervenção direta do Poder Judiciário (v.g., Suécia e Finlândia); em outros, há o compartilhamento das atividades executivas entre juízes e agentes auxiliares da administração da justiça, os quais

\footnotetext{
${ }^{33}$ FREITAS, José Lebre de. Os paradigmas da acção executiva. In: A reforma da acção executiva - trabalhos preparatórios. v. I, Ministério da Justiça, Gabinete de Política Legislativa e Planejamento, Lisboa: 2001, p. 80.

${ }^{34}$ EUROPEAN JUSTICE. Procedures for enforcing a judgment - Germany. Disponível em: https://ejustice.europa.eu/content_procedures_for_enforcing_a_judgment-52-de-en.do?member=1. Acesso em: 17 mar. 2021.
} 
ora se vinculam ao Estado (v.g., Espanha, Itália e Alemanha), ora atuam como profissionais liberais no ambiente da iniciativa privada percebendo remuneração específica para a prática dos atos executivos (v.g., Portugal e França). E há também a possibilidade da autotutela executiva - a qual, contudo, não é objeto deste estudo.

No Brasil, o atual sistema processual também prevê o compartilhamento das atividades executivas entre juízes e oficiais de justiça que atuam como auxiliares da justiça (art. 149 do CPC). Todavia, no caso brasileiro, os oficiais de justiça são servidores públicos ocupantes de cargo público efetivo, aprovados em concurso público de provas ou de provas e títulos (art. 37, II, da CRFB), sujeitos a regime jurídico estatutário (arts. 39 e 40 da CRFB), e vinculados à estrutura organizacional e de pessoal do Poder Judiciário.

Ao magistrado compete, caso não haja disposição legal em sentido diverso, determinar os atos executivos (art. 782 do CPC), como, por exemplo, a inclusão do nome do executado em cadastros de inadimplentes (art. $782, \S 4^{\circ}$, do CPC), o bloqueio de contas bancárias e a indisponibilidade de ativos financeiros (art. 854 do CPC) e a determinação de expedição de ofício para imposição de restrição patrimonial em veículos e imóveis. Além disso, é o juiz a autoridade pública responsável para ordenar o emprego de força policial para efetivar a execução (arts. $782, \S 2^{\circ}$ e $846, \S 2^{\circ}$, do CPC), arrombamento de portas de residência para fins de realização de penhora (art. 846 do $\mathrm{CPC}$ ), e demais medidas executivas como pagamento de multas pecuniárias, busca e apreensão de bens, remoção de pessoas e coisas, desfazimento de obras e impedimento de atividade nociva (art. 536, $\S 1^{\circ}$, do $\mathrm{CPC})$.

Outrossim, é o juiz que determina a intimação do executado para pagamento do débito requerido pelo credor (arts. 523 e 827 a 830 do CPC), sob pena de expedição de mandado de penhora e avaliação (arts. $523, \S 3^{\circ}$ e $829, \S 1^{\circ}$, do CPC). Ademais, a determinação dos atos de expropriação de bens - adjudicação ao exequente, alienação a terceiros por iniciativa particular ou em leilão judicial eletrônico ou presencial, e apropriação de frutos e rendimentos de empresa ou de estabelecimento e de outros bens (art. 825 do CPC) - igualmente são ordenados ou autorizados pelo órgão judicial.

Por seu turno, ao oficial de justiça cabe cumprir os atos executivos determinados pelo juiz (art. 782 do CPC), praticando medidas como, por exemplo, a realização de citações e intimações em processos de execução, penhoras, arrestos, avaliações e descrição 
de bens, e certificação de proposta de autocomposição apresentada por quaisquer das partes (v.g., arts. 154, 829, 830, 836 e 870 do CPC).

O Projeto de Lei (PL) $n^{\circ} .6 .204 / 19,{ }^{35}$ de autoria da Senadora Soraya Thronicke, ao dispor sobre a desjudicialização da execução civil de título executivo judicial e extrajudicial, visa modificar substancialmente o atual panorama da legislação processual executiva brasileira. Isso porque a proposição legislativa acresce ao tabelião de protesto a função de agente de execução, atribuindo-lhe competência, dentre outros atos, para a verificação da regularidade do título executivo; exame de eventual ocorrência de prescrição e decadência; consulta à base de dados para localização do devedor e de seu patrimônio; citação do executado para pagamento; realização de penhora e avaliação de bens; expropriação patrimonial; pagamento ao exequente; e suspenção e extinção da execução (arts. $3^{\circ}$ e $\left.4^{\circ}\right)$.

Uma primeira indagação que surge é se as funções de agente de execução previstas no PL $\mathrm{n}^{\circ}$. 6.204/19 correspondem estritamente à figura do agente de execução português? Embora a nomenclatura seja a mesma e a proposição legislativa tenha declaradamente se inspirado no modelo português, parece-nos que a resposta é negativa, inclusive quanto à própria natureza jurídica.

O agente de execução português, embora atue como auxiliar da administração da justiça, é um profissional liberal de natureza privada cuja categoria profissional é autônoma e regulamentada. Para a prática dos atos executivos, o agente de execução percebe remuneração específica, a título de honorários pagos pelo exequente (com possibilidade de posterior reembolso pelo executado), assim como lhe é devido o reembolso de despesas (v.g., Portaria $\left.n^{\circ} .225 / 2013\right){ }^{36}$

Em Portugal, a escolha do agente de execução pertence ao exequente, o qual o designa "de entre os registados em lista oficial". Se ele não o fizer, a secretaria do juízo designa um agente de execução "segundo a escala constante da lista oficial, através de meios eletrónicos que garantam a aleatoriedade no resultado e a igualdade na distribuição".

35 BRASIL. CÂMARA DOS DEPUTADOS. Projeto de Lei $n^{o}$. 6.204, de 27 de novembro de 2019. Disponível em: https://www25.senado.leg.br/web/atividade/materias/-/materia/139971. Acesso em: 22 abr. 2021.

36 REPÚBLICA PORTUGUESA. Portaria $n^{o}$. 225, de 10 de julho de 2013. Disponível em: http://www.pgdlisboa.pt/leis/lei_mostra_articulado.php?nid=1951\&tabela=leis\&nversao=\&so_miolo=. Acesso em: 22 abr. 2021. 
Ademais, além das hipóteses de "destituição pelo órgão com competência disciplinar", o agente de execução "pode ser substituído pelo exequente" (art. $720 .^{\circ}$ do CPC português).

Diversamente, o PL nº. 6.204/19 não trata o agente de execução propriamente como uma profissão autônoma e específica, mas como um conjunto de funções que são acrescidas às já existentes atribuições regulamentares do tabelião de protesto (art. $3^{\circ}$ ). Por sua vez, o tabelião de protesto exerce seus serviços notariais e de registro "em caráter privado, por delegação do Poder Público" (art. 236, caput, da CRFB), mediante o percebimento de emolumentos relativos aos atos praticados (art. 236, $2^{\circ}$, da CRFB).

Ademais, o ingresso na atividade notarial e de registro está condicionada à prévia

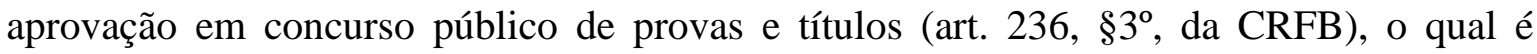
realizado "pelo Poder Judiciário, com a participação, em todas as suas fases, da Ordem dos Advogados do Brasil, do Ministério Público, de um notário e de um registrador" (art. 15 da Lei $\mathrm{n}^{\circ}$. 8.935/1994). O tabelião de protesto é profissional com formação jurídica (arts. $3^{\circ} \mathrm{e}$ 14, V, da Lei $\mathrm{n}^{\circ}$. 8.935/1994), que atua como delegatário de função pública atribuída pelo Estado consistente no exercício, com fé pública, da atividade notarial e de registro (art. $3^{\circ}$ da Lei $\left.n^{\circ} .8 .935 / 1994\right)$.

As diferenças quanto à natureza jurídica do agente de execução entre os dois países trazem reflexões importantes. Dito de outro modo, é possível apontar pontos positivos e negativos quanto à opção do PL nº . 6.204/19 de atribuir as funções de agente de execução aos tabeliões de protesto.

A forma de designação do agente de execução é diversa: enquanto em Portugal ele é designado por critérios subjetivos escolhidos pelo exequente, no PL $n^{\circ}$. 6.204/19 ele é um profissional aprovado em prévio concurso público de provas e títulos, e que tem "todas as suas atribuições definidas em lei, não se submetendo, portanto, às vontades do credor”. Assim, o agente de execução, nos moldes idealizados pelo PL $n^{\circ}$. 6.204/19, não se demonstra como um agente a serviço do credor, nem tampouco como seu mandatário ou representante. ${ }^{37}$

Ademais, a partir do momento em que fossem atribuídas as competências para a prática de atos executivos, os agentes de execução passariam a ser enquadrados como

\footnotetext{
${ }^{37}$ FARIA, Márcio Carvalho. Primeiras impressões sobre o Projeto de Lei 6.204/2019: críticas e sugestões acerca da tentativa de se desjudicializar a execução civil brasileira (parte dois). Revista de Processo, v. 314, p. 371-391, abr. 2021.
} 
auxiliares da justiça. Por conseguinte, sujeitar-se-iam aos deveres de boa-fé objetiva e cooperação processuais (arts. $5^{\circ}$ e $6^{\circ}$ do $\mathrm{CPC}$ ), inclusive com a submissão às hipóteses de impedimento e suspeição (art. 148, II, do CPC).

Além disso, assim como já ocorre em Portugal, também no Brasil os agentes de execução se submeteriam a órgãos de controle. No caso brasileiro, a fiscalização dos tabeliões de protesto é exercida pelo próprio Poder Judiciário (arts. 103-B, §4º , III e 236, $\S 1^{\circ}$, da CRFB e arts. 37 e 38 da Lei $n^{\circ}$. 8.935/1994); já no exemplo português, os agentes de execução são funcionalmente fiscalizados pela Comissão para o Acompanhamento dos Auxiliares da Justiça (CAAJ), criada pela Lei $\mathrm{n}^{\circ}$. 77/2013 como entidade administrativa independente, dotada de personalidade jurídica, autonomia administrativa e financeira e património próprio, e com competência para o acompanhamento, fiscalização e disciplina dos auxiliares da justiça. ${ }^{38}$

Portanto, ao menos em tese, não se verifica violação à imparcialidade na atribuição de funções executivas aos tabelionatos de protesto. ${ }^{39} \mathrm{Na}$ verdade, na medida em que o agente de execução brasileiro atuaria no âmbito cartorário, as suas funções executivas seriam exercidas no bojo de devido processo administrativo processado na esfera extrajudicial. Por consequência, competiria ao tabelião não apenas assegurar o adequado exercício do contraditório e da ampla defesa (art. $5^{\circ}, \mathrm{LV}$, da CRFB), como também conduzir o procedimento com o devido respeito a todas as demais normas e garantias fundamentais do processo civil aplicáveis supletiva e subsidiariamente aos processos administrativos (art. 15 do CPC), como aquelas previstas na Constituição, no CPC e na Lei $n^{\circ} .9 .784 / 1999 .^{40}$

38 REPÚBLICA PORTUGUESA. Lei $n^{o}$. 77, de 21 de novembro de 2013. Disponível em: https://dre.pt/web/guest/pesquisa-avancada/-

/asearch/503832/details/maximized?advanced.search=Pesquisa+Avan\%C3\%A7ada\&anoDR=2013\&sortOrde $\mathrm{r}=\mathrm{ASC} \&$ tipo=\%22Lei\%22\&types=SERIEI\&numero=77. Acesso em: 22 abr. 2021.

${ }^{39}$ HILL, Flávia Pereira. Desjudicialização da execução civil: reflexões sobre o Projeto de Lei no ${ }^{\circ}$ 6.204/2019. Revista Eletrônica de Direito Processual - REDP, ano 14, v. 21, n. 3, Rio de Janeiro, p. 181-182, set./dez. 2020; FARIA, Márcio Carvalho. Primeiras impressões sobre o Projeto de Lei 6.204/2019: críticas e sugestões acerca da tentativa de se desjudicializar a execução civil brasileira (parte dois). Revista de Processo, v. 314, São Paulo, p. 371-391, abr. 2021.

40 Nesse particular, Flávia Pereira Hill enumera os seguintes elementos mínimos para uma concepção democrática de "devido processo legal extrajudicial" que resguarde as garantias fundamentais do processo e não importe em "retrocesso garantístico": a) imparcialidade e independência; b) controle externo; c) publicidade; d) previsibilidade do procedimento; e) contraditório. (HILL, Flávia Pereira. Desjudicialização e acesso à justiça além dos tribunais: pela concepção de um devido processo legal extrajudicial. Revista Eletrônica de Direito Processual-REDP, ano 15, v. 22, n. 1, p. 379-408, Rio de Janeiro, jan./abr. 2021). 
De outro turno, há a necessidade de tratamento específico quanto ao sistema recursal e das tutelas provisórias executivas que devam ser garantidas duramente o processamento da execução perante o agente executivo. No sistema português (arts. $723 .^{\circ} \mathrm{e}$ 726. ${ }^{\circ}$ do CPC português), os atos decisórios, incluindo as decisões liminares, são de competência e responsabilidade do juiz.

Qual será o tratamento mais adequado para a legislação brasileira? A suscitação de dúvida perante o próprio agente executivo, reclamação junto aos órgãos administrativos de fiscalização e impugnação diretamente ao Poder Judiciário (art. 21 do PL nº. 6.204/19) consistem em alternativas para substituir o sistema recursal tradicionalmente previsto no CPC - embora o PL $\mathrm{n}^{\circ}$. 6.204/2019 contenha brechas no curso do procedimento que merecem previsão de impugnação específica.

No sistema português não foi abandonada a participação nem a responsabilidade do juiz. Aliás, os atos decisórios mais importantes da execução, e o próprio controle da atividade do agente de execução no procedimento executivo, são de responsabilidade do magistrado (v.g., arts. $723 .^{\circ}$ e $726 .^{\circ}$ do CPC português).

Nesse ponto, é possível sustentar que alguns dos atos executivos atribuídos pelo PL $n^{\circ}$. 6.204/2019 ao agente de execução deveriam, à semelhança com o sistema português, ser deslocados para a figura do juiz (v.g., incisos I, V e VII do art. $4^{\circ}$ ). Embora o STF tenha declarado a constitucionalidade da execução extrajudicial de dívidas hipotecárias, ainda paira dúvidas sobre a possibilidade constitucional de atribuir ao agente cartorário a competência para proceder com atos de invasão ou constrição patrimonial (v.g., a própria expropriação).

Aliás, a partir da tradição portuguesa, é possível afirmar que, se de um lado é verdadeira a afirmação de que a execução pode chegar ao final sem a participação do juiz, de outro também é correta a indicação de que ele atua como "controlador" da atividade do agente de execução. Há, pois, uma participação conjunta entre juiz e agente de execução, ficando o magistrado como agente fiscalizador e julgador dos incidentes que possam surgir na execução. Ainda que o objetivo principal do PL no . 6.204/2019 seja assegurar maior efetividade e celeridade à execução, não se pode descurar da imprescindível discussão sobre a constitucionalidade de eventual violação ao devido processo legal como condição inarredável para a privação de bens (art. $5^{\circ}$, LIV, da CRFB). 
Igualmente é importante indagar: nos casos de danos praticados pelo agente de execução, a quem compete a responsabilidade? Em Portugal, parte-se de uma premissa: o agente de execução, apesar de profissional liberal (agente privado), atua no exercício de função pública, inclusive sob a fiscalização estatal do Poder Judiciário. O juiz, portanto, "legitima", "referenda", "supervisiona" e "corrige" a atuação do agente de execução, que inclusive pode provocá-lo para solucionar eventual incidente processual. ${ }^{41}$

Logo, a responsabilidade pode ser direta na pessoa do agente executivo ou indireta em face do próprio Estado. O juiz, ao praticar, fiscalizar ou autorizar os atos praticados pelo agente executivo, também está sujeito à responsabilidade (pessoal ou em face do ente público que o remunera), que também é ampliada para os atos do agente de execução e do próprio exequente (ao nomear o agente executivo ou mesmo promover demanda posteriormente considerada injusta). ${ }^{42}$

Já o PL nº. 6.204/2021 prevê, no caso do Brasil, que a responsabilidade civil, administrativa e criminal do agente de execução será objeto de legislação própria e específica $\left(\operatorname{art.} 4^{\circ}, \S 4^{\circ}\right)$. Ademais, como auxiliar de justiça, aplicar-se-ia ao agente de execução o mesmo regime de responsabilidade civil previsto no art. 155 do CPC, sem esquecer também o regime próprio de responsabilidade civil e criminal aplicável aos tabeliões e registradores (arts. 22 a 24 da Lei $n^{\circ}$. 8.935/1994).

A escolha do PL nº. 6.204/19 de atribuir as funções de agente de execução somente aos tabeliões de protesto também é alvo de críticas. Nesse ponto, Márcio Carvalho Faria

\footnotetext{
${ }^{41}$ Em decorrência do enquadramento do agente de execução, Teixeira de Souza faz as seguintes considerações: "deste enquadramento legal podem retirar-se várias conclusões. Uma delas - directamente decorrente da circunstância de o solicitador de execução actuar na dependência funcional do juiz da execução - é a de que este solicitador, apesar de ser uma entidade privada, exerce funções públicas, pelo que se está perante um exemplo de exercício privado de funções públicas. Uma outra conclusão é a de que o juiz de execução pode supervisionar, mesmo que por iniciativa própria, a actuação do solicitador de execução, nomeadamente para efeitos de verificação do cumprimento dos deveres funcionais e profissionais por este solicitador (cfr., sobre a possibilidade de destituição oficiosa do solicitador pelo juiz de execução, $\operatorname{art}^{\circ} .808^{\circ}$, $\left.\mathrm{n}{ }^{\circ} 4\right)$. Finalmente, uma terceira conclusão é a de que o solicitador de execução pode solicitar, a qualquer momento, a apreciação de uma questão pelo juiz de execução (cfr. $\operatorname{art}^{\circ} 809^{\circ}, \mathrm{n}^{\circ} 1$, al. D), ficando, naturalmente, vinculado ao sentido da decisão deste juiz." (SOUZA, Miguel Teixeira de. A reforma da acção executiva. Lisboa: LEX, 2004, p. 18).

42 "O exercício do direito de acção, ou de qualquer outro direito processual, encontra-se, como não podia deixar de ser, sujeito a limites impostos pela proibição de abuso de direito. Tal como o civil, o direito processual está sujeito e subordinado ao princípio da boa fé" (ALBUQUERQUE, Pedro de. Responsabilidade processual por litigância de má fé, abuso de direito e responsabilidade civil em virtude de actos praticados no processo. Acórdão do Tribunal da Relação do Porto de 13 julho de 2006. Separata da Revista da Ordem dos Advogados. Ano 66, II, Lisboa, Setembro 2006, p. 903).
} 
questiona a própria exclusividade conferida à proposição legislativa aos tabelionatos de protesto, refletindo sobre a possibilidade de outorgar o exercício das funções de agente de execução a outras profissões, tais como: advogados; agentes de execução como nova categoria profissional autônoma (tal qual já ocorre no Brasil com os conciliadores e mediadores judiciais); todos os notários e registradores do país, e não apenas os tabeliões de protesto. ${ }^{43}$

Outrossim, é de se indagar também acerca do esvaziamento das funções dos oficiais de justiça, os quais também representam uma categoria profissional importante na esfera da administração da justiça e cuja remuneração é custeada com recursos públicos.

É recorrente a afirmação de que o Poder Judiciário brasileiro é um dos mais caros do mundo. Conforme o último relatório "Justiça em Números" divulgado pelo CNJ, referente ao ano-base de 2019, "as despesas totais do Poder Judiciário somaram R \$ 100,2 bilhões", correspondendo "a 1,5\% do Produto Interno Bruto (PIB) nacional, ou a 2,7\% dos gastos totais da União, dos estados, do Distrito Federal e dos municípios”. Desse total, os "gastos com recursos humanos são responsáveis por 90,6\%" e "compreendem, além da remuneração com magistrados, servidores, inativos, terceirizados e estagiários, todos os demais auxílios e assistências devidos, tais como auxílio-alimentação, diárias, passagens, entre outros".

Quanto a essas despesas com pessoal, o seu detalhamento "mostra que 85,9\% dos gastos destinam-se ao pagamento de subsídios e remunerações dos magistrados e servidores ativos e inativos, que incluem também pensões, impostos de renda e encargos sociais; 6,9\% são referentes ao pagamento de benefícios (ex.: auxílio-alimentação, auxíliosaúde); 2,4\% correspondem ao pagamento de despesas em caráter eventual e indenizatório, como diárias, passagens e auxílio-moradia; $4 \%$ são gastos com terceirizados e 0,8\% com estagiários". Em números absolutos, os gastos com recursos humanos alcançam R\$ 90,8 bilhões.

É claro que as despesas com pessoal no Poder Judiciário abrangem diversas categorias profissionais, incluindo os magistrados e outros servidores públicos que ocupam

\footnotetext{
${ }^{43}$ FARIA, Márcio Carvalho. Primeiras impressões sobre o Projeto de Lei 6.204/2019: críticas e sugestões acerca da tentativa de se desjudicializar a execução civil brasileira (parte dois). Revista de Processo, v. 314, p. 371-391, abr. 2021.
} 
cargos diferentes dentro da administração da justiça. Embora o CNJ não tenha divulgado estatísticas específicas sobre os oficiais de justiça, alguns dados são elucidativos.

Em 2019, o Poder Judiciário nacional contava com o total de 446.142 pessoas em sua força de trabalho. Desse total, 60,1\% - ou seja, 268.175 - eram servidores, incluindo o quadro efetivo, os requisitados e os cedidos de outros órgãos pertencentes ou não à estrutura do Poder Judiciário, além dos comissionados sem vínculo efetivo, excluindo-se os servidores do quadro efetivo que estão requisitados ou cedidos para outros órgãos.

Considerando apenas esses servidores, 227.189 pertenciam ao quadro efetivo (84,7\%), 21.609 estavam requisitados e cedidos de outros órgãos $(8,1 \%)$ e 18.775 eram comissionados sem vínculo efetivo (7\%). Ainda levando em consideração apenas os servidores, 211.295 (78,8\%) estavam lotados na área judiciária e 56.880 (21,2\%) na área administrativa. Os oficiais de justiça pertencem ao quadro efetivo e estão lotados na área judiciária.

As despesas com servidores representaram, em 2019, uma média mensal de aproximadamente $\mathrm{R} \$ 16,3$ mil por servidor, incluindo os pagamentos de remunerações, indenizações, encargos sociais, previdenciários, impostos de renda e despesas com viagens a serviço (passagens aéreas e diárias). Portanto, os servidores efetivos da administração judiciária - aí incluídos os oficiais de justiça - custaram mensalmente aos cofres públicos uma média de mais de 16 salários mínimos (considerando o valor de salário mínimo de $\mathrm{R} \$ 998,00$ em 2019). Considerando apenas o total de servidores do quadro efetivo lotados na área judiciária, o valor médio mensal de dispêndios foi de aproximadamente $\mathrm{R} \$ 3,5$ bilhões. $^{44}$

Nesse contexto, é questionável a opção legislativa de tornar obrigatória a provocação dos tabelionatos de protesto para a prática de atos executivos, ao mesmo tempo em que vem acompanhada da drástica redução do leque de funções atribuídas aos oficiais de justiça.

Em termos econômico-político-sociais, como sustentar perante a sociedade (contribuinte) o pagamento do mesmo valor salarial a servidores públicos que, amparados pela garantia constitucional da irredutibilidade remuneratória (art. 37, XV, da CRFB),

\footnotetext{
${ }^{44}$ BRASIL. CONSELHO NACIONAL DE JUSTIÇA. Justiça em Números 2020 - ano-base 2019, p. 74-91. Disponível em: https://www.cnj.jus.br/pesquisas-judiciarias/justica-em-numeros/. Acesso em: 22 abr. 2021.
} 
teriam uma diminuição substancial das suas cargas de trabalho em um universo de milhões de processos judiciais na fase executiva? Nunca é demais lembrar que, do total de 77 milhões de casos em tramitação no ano de 2019, aproximadamente $17 \%$ se referiam às execuções não-fiscais - ou seja, mais de 13 milhões de processos. ${ }^{45}$

Também não parece adequado tratar o Poder Judiciário, em todas as hipóteses e invariavelmente, como a ultima ratio. ${ }^{46}$ Desde a sua origem, o Sistema Multiportas idealizado por Frank Sander como Multi-Door Courthouse System - propõe a substituição do modelo tradicional e estático de tribunal por um centro de solução de disputas (dispute resolution center) que forneça simultaneamente, de forma coordenada, integrada, dinâmica, flexível e centralizada, as múltiplas portas de solução de disputas (multi-door) ${ }^{47}$

Trata-se, pois, de conceber o método judicial como mais uma das alternativas adequadas de resolução de controvérsias - e não necessariamente a última ou a residual -, dentro de uma "teia de cooperação" que proporcione a integração permanente e entrelaçada entre os múltiplos métodos. ${ }^{48} \mathrm{O}$ modelo multiportas visa consagrar um sistema jurídica que ofereça uma variedade concomitante de técnicas integradas, complementares e adequadas de resolução de conflitos.

De fato, nem sempre o método extrajudicial será o mais apropriado para a solução da causa, assim como não se pode aprioristicamente excluir o processo judicial como a instância adequada para uma primeira ou única tentativa de resolução da contenda. O que importa é que o sistema jurídico disponibilize o método que melhor se adeque às

\footnotetext{
${ }^{45}$ BRASIL. CONSELHO NACIONAL DE JUSTIÇA. Justiça em Números 2020, p. 150-160. Disponível em: https://www.cnj.jus.br/pesquisas-judiciarias/justica-em-numeros/. Acesso em: 23 abr. 2021.

${ }^{46}$ Nesse ponto, com as devidas vênias, apresenta-se discordância com a posição de autores como: CAMBI, Eduardo; VASCONCELOS, João Paulo A. Desjudicialização de políticas públicas e o Novo Código de Processo Civil - contributo do Ministério Público e da Advocacia Pública à solução extrajudicial de conflitos. In: ARAÚJO, José Henrique Mouta; CUNHA, Leonardo Carneiro da (Coord.). DIDIER JR., Fredie (Coord. Geral). Advocacia Pública. Salvador: Jus Podivm, 2015, p. 105-107; HILL, Flávia Pereira. Desjudicialização e acesso à justiça além dos tribunais: pela concepção de um devido processo legal extrajudicial. Revista Eletrônica de Direito Processual - REDP, ano 15, v. 22, n. 1, p. 379-408, Rio de Janeiro, jan./abr. 2021.

${ }^{47}$ SANDER, Frank E. A. Varieties of Dispute Processing. Eagan: West Publishing Company, 1976, p. 112113; GRAY, Ericka B. Creating History: The Impact of Frank Sander on ADR in the Courts. Negotiation Journal, Harvard Law School, Volume 22, Issue 4, p. 446, April 2006.

${ }^{48}$ CUNHA, Leonardo Carneiro da; AZEVEDO NETO, João Luiz Lessa de. A mediação e a conciliação no projeto do novo CPC: meios integrados de resolução de disputas. Revista de Direito, n. 5, p. 272, Santa Cruz do Sul, out. 2014.
} 
circunstâncias específicas do caso concreto, conforme as necessidades das partes e as exigências do direito material.

O encontro entre as necessidades da causa com a "porta" adequada - isto é, o método de solução de disputa mais apropriado - consiste no ponto nuclear do Multi-Door Courthouse System. ${ }^{49}$ A escolha da técnica mais apropriada para a resolução de um conflito específico está baseada em um juízo de adequação, ${ }^{50}$ e não em uma imposição normativa.

Por essa razão, parece discutível a opção do PL nº. 6.204/19 de tornar obrigatória a prática dos atos executivos na esfera cartorária. A revisitação do conceito de jurisdição e de acesso à justiça (art. 5, $\mathrm{XXXV}$, da CRFB), a partir da sua identificação com os variados métodos de solução de conflitos - inclusive os extrajudiciais -, não parece autorizar a exclusão da jurisdição estatal como instância executiva. Melhor seria que as funções executivas atribuídas pelo PL $\mathrm{n}^{\circ}$. 6.204/19 aos tabelionatos de protesto fosse uma faculdade do requerente, tal qual já ocorre com o inventário e partilha por escritura pública (art. 610, §1 ${ }^{\circ}$, do CPC), separação e divórcio consensuais (art. 733 do CPC), usucapião extrajudicial (arts. 1.071 do CPC e 216-A da Lei $\mathrm{n}^{\circ}$. 6.015/1973), retificação de registro civil (art. 110 da Lei $n^{\circ}$. 6.015/1973) e alienação por iniciativa particular (art. 880 do CPC).

Finalmente, um último ponto de reflexão diz respeito à própria efetividade da proposta legislativa, a qual, em última análise, propõe o deslocamento da atividade executiva do Poder Judiciário para os tabelionatos de protesto. Dito de outro modo, o PL $\mathrm{n}^{\mathrm{o}}$. 6.204/19 parece se limitar a "transferir o problema" da inefetividade e ineficiência de milhões de execuções civis, mas sem enfrentar uma das causas principais do "gargalo das execuções", qual seja, a localização do devedor e, principalmente, do seu patrimônio expropriável.

Em Portugal, o agente de execução, a partir de solicitação do credor e inclusive no PEPEX, tem a prerrogativa de consultar previamente a situação patrimonial do devedor a

\footnotetext{
${ }^{49}$ STEDMAN, Barbara Epstein. Multi-option justice at the Middlesex Multi-Door Courthouse. In: SMITH, Roger (edit.). Achieving Civil Justice: Appropriate dispute resolution for the 1990s. London: Legal Action Group, 1996, p. 120, tradução nossa.

${ }^{50}$ DIDIER JR., Fredie; ZANETI JR., Hermes. Justiça multiportas e tutela constitucional adequada: autocomposição em direitos coletivos. In: ZANETI JR., Hermes; CABRAL, Trícia Navarro Xavier (Coord.). DIDIER JR., Fredie (Coord. Geral). Justiça Multiportas: Mediação, Conciliação, Arbitragem e outros meios de solução adequada de conflitos. Salvador: Jus Podivm, 2016, p. 61.
} 
partir de uma sólida e centralizada base de dados. ${ }^{51}$ No Brasil, contudo, as deficiências no acesso de informações sobre o acervo de bens de devedores são significativas, a ponto de inexistir, por exemplo, uma única rede eletrônica que concentre e interligue os dados dos cartórios de registros de imóveis de todo o país.

A dificuldade na localização de bens é vivenciada pelo próprio Poder Judiciário, o qual, não raras vezes, é incapaz de encontrar patrimônio passível de penhora, em que pesem as sucessivas e demoradas tentativas em sistemas não-interligados como SISBAJUD, BACENJUD, RENAJUD e INFOJUD. Soma-se a isso a facilidade da esquiva do pagamento de débitos, mediante a criação, por exemplo, de sofisticadas estruturas societárias ou a utilização desvirtuada do instituto da recuperação judicial de sociedade empresária.

É importante discutir com seriedade se a proposição legislativa resolverá o significativo entrave da localização, penhora e avaliação de bens. Será que, com o simples deslocamento do procedimento executivo, o executado realmente apresentará bens à penhora, efetuará o pagamento e cooperará com a solução dos atos expropriatórios? Se a resposta for negativa, corre-se o risco de apenas mudar de posição, transportando o estado de crise da execução para o agente cartorário.

A rigor, é certo que nenhuma modificação do sistema de medidas executivas surtirá o efeito desejado se não enfrentar os reais "pontos de estrangulamento" que travam a recuperação de créditos e a satisfação forçada de obrigações. A reforma da execução civil deve vir acompanhada do aperfeiçoamento das técnicas de localização do devedor e de investigação patrimonial, além de um eficiente sistema de combate à ocultação ilegítima de bens com o intuito de fraudar credores.

\section{CONSIDERAÇÕES FINAIS}

Tradicionalmente, a admissibilidade da prática de atos executivos fora da esfera judicial encontra forte resistência no Brasil. Embora essa realidade vem sendo questionada por parcela da comunidade jurídica contemporânea, não é raro se deparar com uma

\footnotetext{
${ }^{51}$ MEDEIROS NETO, Elias Marques de. O procedimento extrajudicial pré-executivo: lei 32 de 30 de maio de 2014: inspiração para o sistema processual no Brasil. Verbatim: São Paulo, 2015.
} 
interpretação restritiva do princípio da inafastabilidade da jurisdição estatal (art. $5^{\circ}$, XXXV, da CRFB) que atribua ao juiz a exclusividade da prática de medidas de cumprimento forçado de obrigações.

Por outro lado, em alguns países da Europa, verifica-se a consagração de uma tradição jurídica favorável à adoção de práticas de cumprimento forçado de obrigações fora e para além do Poder Judiciário. É nítido que as características desjudicializantes desses sistemas executivos europeus vêm influenciando, em maior ou menor medida, o atual debate doutrinário e legislativo sobre o assunto também no Brasil - como é exemplo o PL $n^{\circ} .6 .204 / 2019$.

O tratamento jurídico e o entendimento jurisprudencial acerca da execução civil no ordenamento brasileiro parecem apontar em direção à expansão das alternativas de utilização de variadas técnicas judiciais e extrajudiciais, dentro da ideia de desenvolvimento de um Sistema Multiportas de Execução ${ }^{52}$ que congregue múltiplas, integradas, complementares e adequadas técnicas executivas. A tendência, em um espaço de tempo não muito longo, indica uma possível inovação legislativa que disponha sobre a desjudicialização não apenas do emprego de medidas executivas, como também do próprio processo de execução.

O PL n ${ }^{\circ}$. 6.204/2019 se empenha nesse desiderato, ao propor a transferência da atividade executiva para os tabelionatos de protesto. Seguramente, não se trata de uma mera importação do sistema executivo de Portugal, em virtude, por exemplo, de diferenças relativas à natureza jurídica do agente de execução e da ausência de proposta de criação de um procedimento executivo extrajudicial de caráter pré-processual (como o PEPEX português). Por outro lado, é evidente também que a proposição legislativa busca, de certa forma, uma aproximação teórica e prática com alguns modelos executivos europeus.

O amplo debate acerca das ideias constantes do PL nº 6.204/2019 é necessário, uma vez que a modificação proposta no sistema executivo é profunda e tem natureza

\footnotetext{
${ }^{52}$ Sobre o Sistema Multiportas de Execução, conferir: FRANCO, Marcelo Veiga; RETES, Tiago Augusto Leite. Sistema Multiportas de Execução. Disponível em: https://www.jota.info/opiniao-eanalise/artigos/sistema-multiportas-execucao-justica-processos-30032021. Acesso em: 22 abr. 2021; FARIA, Márcio Carvalho. Primeiras impressões sobre o PL 6.204/2019: críticas e sugestões acerca da tentativa de se desjudicializar a execução civil brasileira (parte um). Revista de Processo, v. 313, p. 393-414, mar. 2021; DIDIER JR., Fredie; SICA, Heitor. Live Jurídica - Execução Extrajudicial. Disponível em: https://www.youtube.com/watch?v=2dANrtyoRos. Acesso em: 22 abr. 2021.
} 
estrutural. Com isso, espera-se que as reflexões e ponderações ora apresentadas tenham alcançado o objetivo de contribuir com as discussões sobre a matéria.

\section{REFERÊNCIAS:}

ALBUQUERQUE, Pedro de. Responsabilidade processual por litigância de má fé, abuso de direito e responsabilidade civil em virtude de actos praticados no processo. Acórdão do Tribunal da Relação do Porto de 13 julho de 2006. Separata da Revista da Ordem dos Advogados. Ano 66, II, Lisboa, Setembro 2006.

BRASIL. CÂMARA DOS DEPUTADOS. Projeto de Lei $n^{o}$. 6.204, de 27 de novembro de 2019. Disponível em: https://www25.senado.leg.br/web/atividade/materias//materia/139971. Acesso em: 22 abr. 2021.

BRASIL. CONSELHO NACIONAL DE JUSTIÇA. Justiça em Números 2020 - ano-base 2019, p. 74-91. Disponível em: https://www.cnj.jus.br/pesquisas-judiciarias/justicaem-numeros/. Acesso em: 22 abr. 2021.

BRASIL. SUPERIOR TRIBUNAL DE JUSTIÇA. RECURSO ESPECIAL: RESP 1.782.418/RJ, Relatora Ministra Nancy Andrighi, Terceira Turma, julgado em 23/04/2019, DJe 26/04/2019.

BRASIL. SUPERIOR TRIBUNAL DE JUSTIÇA. RECURSO ESPECIAL: RESP 1.807.923/SC, Relator Ministro Og Fernandes, Primeira Seção, julgado em 24/02/2021, DJe 11/03/2021.

BRASIL. SUPREMO TRIBUNAL FEDERAL. RECURSO EXTRAORDINÁRIO: RE 627.106/PR, Relator Ministro Dias Toffoli, Tribunal Pleno, julgado em 08/04/2021, extrato da ata de julgamento DJe 14/04/2021.

CAMBI, Eduardo; VASCONCELOS, João Paulo A. Desjudicialização de políticas públicas e o Novo Código de Processo Civil - contributo do Ministério Público e da Advocacia Pública à solução extrajudicial de conflitos. In: ARAÚJO, José Henrique Mouta; CUNHA, Leonardo Carneiro da (Coord.). DIDIER JR., Fredie (Coord. Geral). Advocacia Pública. Salvador: Jus Podivm, 2015. 
COMMISSAIRES DE JUSTICE - CHAMBRE NATIONALE. Les missions de l'huissier de justice. Disponível em: https://www.huissier-justice.fr/nos-missions/. Acesso em: 22 abr. 2021.

CUNHA, Leonardo Carneiro da; AZEVEDO NETO, João Luiz Lessa de. A mediação e a conciliação no projeto do novo CPC: meios integrados de resolução de disputas. Revista de Direito, n. 5, Santa Cruz do Sul, out. 2014.

DIDIER JR., Fredie. Curso de Direito Processual Civil: Introdução ao Direito Processual Civil, Parte Geral e Processo do Conhecimento. Salvador: JusPodivm, 2019.

DIDIER JR., Fredie; SICA, Heitor. Live Jurídica - Execução Extrajudicial. Disponível em: https://www.youtube.com/watch?v=2dANrtyoRos. Acesso em: 22 abr. 2021.

DIDIER JR., Fredie; ZANETI JR., Hermes. Justiça multiportas e tutela constitucional adequada: autocomposição em direitos coletivos. In: ZANETI JR., Hermes; CABRAL, Trícia Navarro Xavier (Coord.). DIDIER JR., Fredie (Coord. Geral). Justiça Multiportas: Mediação, Conciliação, Arbitragem e outros meios de solução adequada de conflitos. Salvador: Jus Podivm, 2016.

EUROPEAN JUSTICE. Procedimientos de ejecución de una sentencia - España. Disponível em: https://ejustice.europa.eu/content_procedures_for_enforcing_a_judgment-52-eses.do?member=1. Acesso em: 17 mar. 2021.

EUROPEAN JUSTICE. Procedures for enforcing a judgment - Finland. Disponível em: https://e-justice.europa.eu/content_procedures_for_enforcing_a_judgment-52-fien.do?member=1. Acesso em: 19 abr. 2021.

EUROPEAN JUSTICE. Procedures for enforcing a judgment - France. Disponível em: https://e-justice.europa.eu/content_procedures_for_enforcing_a_judgment-52-fren.do?member=1. Acesso em: 20 abr. 2021.

EUROPEAN JUSTICE. Procedures for enforcing a judgment - Germany. Disponível em: https://e-justice.europa.eu/content_procedures_for_enforcing_a_judgment-52-deen.do?member=1. Acesso em: 17 mar. 2021 .

EUROPEAN JUSTICE. Procedures for enforcing a judgment - Italy. Disponível em: https://e-justice.europa.eu/content_procedures_for_enforcing_a_judgment-52-iten.do?member=1. Acesso em: 20 abr. 2021. 
EUROPEAN JUSTICE. Procedures for enforcing a judgment - Portugal. Disponível em: https://ehttps://ejustice.europa.eu/content_procedures_for_enforcing_a_judgment-52-pten.do?member=1. Acesso em: 21 abr. 2021.

EUROPEAN JUSTICE. Procedures for enforcing a judgment - Sweden. Disponível em: https://e-justice.europa.eu/content_procedures_for_enforcing_a_judgment-52-seen.do?member=1. Acesso em: 17 mar. 2021.

FARIA, Márcio Carvalho. Primeiras impressões sobre o PL 6.204/2019: críticas e sugestões acerca da tentativa de se desjudicializar a execução civil brasileira (parte um). Revista de Processo, v. 313, p. 393-414, mar. 2021.

FARIA, Márcio Carvalho. Primeiras impressões sobre o Projeto de Lei 6.204/2019: críticas e sugestões acerca da tentativa de se desjudicializar a execução civil brasileira (parte dois). Revista de Processo, v. 314, p. 371-391, abr. 2021.

FRANCO, Marcelo Veiga; RETES, Tiago Augusto Leite. Sistema Multiportas de Execução. Disponível em: https://www.jota.info/opiniao-e-analise/artigos/sistemamultiportas-execucao-justica-processos-30032021. Acesso em: 22 abr. 2021.

FREITAS, José Lebre de. Os paradigmas da acção executiva. In: A reforma da acção executiva - trabalhos preparatórios. v. I, Ministério da Justiça, Gabinete de Política Legislativa e Planejamento, Lisboa: 2001.

GOBIERNO DE ESPAÑA. Constitución Española. Disponível em: https://www.boe.es/buscar/act.php?id=BOE-A-1978-31229. Acesso em: 20 abr. 2021.

GOBIERNO DE ESPAÑA. Letrados de la Administración de Justicia. Disponível em: https://www.mjusticia.gob.es/ca/ciudadanos/empleo-publico/acceso-convocatoriasperfiles/secretarios-judiciales. Acesso em: 21 abr. 2021.

GOBIERNO DE ESPAÑA. Ley 1/2000, de 7 de enero, de Enjuiciamiento Civil. Disponível em: https://www.boe.es/buscar/act.php?id=BOE-A-2000-323. Acesso em: 20 abr. 2021.

GRAY, Ericka B. Creating History: The Impact of Frank Sander on ADR in the Courts. Negotiation Journal, Harvard Law School, Volume 22, Issue 4, April 2006. 
HILL, Flávia Pereira. Desjudicialização da execução civil: reflexões sobre o Projeto de Lei n 6.204/2019. Revista Eletrônica de Direito Processual-REDP, ano 14, v. 21, n. 3, Rio de Janeiro, p. 164-205, set./dez. 2020.

HILL, Flávia Pereira. Desjudicialização e acesso à justiça além dos tribunais: pela concepção de um devido processo legal extrajudicial. Revista Eletrônica de Direito Processual-REDP, ano 15, v. 22, n. 1, p. 379-408, Rio de Janeiro, jan./abr. 2021.

INTERNATIONAL INSTITUTE FOR THE UNIFICATION OF PRIVATE LAW UNIDROIT. ALI / UNIDROIT Principles of Transnational Civil Procedure. 13 out. 2020. Disponível em: https://www.unidroit.org/instruments/civil-procedure/aliunidroit-principles. Acesso em: 16 mar. 2021.

JACOBSSON. Enforcement proceedings in Sweden. RHDI 50, 1997.

KENNETT, Wendy. The enforcement of judgments in Europe. Oxford: Oxford, 2000.

KOULU. Enforcement in Finland. RHDI 50, 1997.

KRONOFOGDEN. Veredict for an order to pay. Disponível em: https://www.kronofogden.se/en-GB/Utslag.html. Acesso em: 17 mar. 2021.

MEDEIROS NETO, Elias Marques de. O procedimento extrajudicial pré-executivo: lei 32 de 30 de maio de 2014: inspiração para o sistema processual no Brasil. Verbatim: São Paulo, 2015.

MOUTA, José Henrique; FRANCO, Marcelo Veiga. A desjudicialização da execução fiscal: reflexões sobre o PL $\mathrm{n}^{\mathrm{o}}$ 4.257/2019. Disponível em: https://www.conjur.com.br/2021-abr-09/araujo-franco-reflexoes-projeto-lei42572019. Acesso em: 26 abr. 2021.

NÓBREGA, Guilherme Pupe da. Reflexões sobre a atipicidade das técnicas executivas e o artigo 139, IV, do $C P C$ de 2015. Disponível em: https://www.migalhas.com.br/coluna/processo-e-procedimento/243746/reflexoessobre-a-atipicidade-das-tecnicas-executivas-e-o-artigo-139--iv--do-cpc-de-2015. Acesso em: 19 abr. 2021.

REPUBBLICA ITALIANA. Codice di procedura civile. Disponível em: https://www.altalex.com/documents/codici-altalex/2015/01/02/codice-di-proceduracivile. Acesso em: 20 abr. 2021. 
REPÚBLICA PORTUGUESA. Lei $n^{o}$. 32/2014. Disponível em: https://dre.pt/pesquisa//search/25345939/details/maximized. Acesso em: 21 abr. 2021.

REPÚBLICA PORTUGUESA. Lei $n^{o}$. 77, de 21 de novembro de 2013. Disponível em: https://dre.pt/web/guest/pesquisa-avancada//asearch/503832/details/maximized?advanced.search=Pesquisa+Avan\%C3\%A7ada $\&$ anoDR=2013\&sortOrder=ASC \&tipo=\%22Lei\%22\&types=SERIEI\&numero=77 Acesso em: 22 abr. 2021.

REPÚBLICA PORTUGUESA. Portaria $n^{o}$. 225, de 10 de julho de 2013. Disponível em: http://www.pgdlisboa.pt/leis/lei_mostra_articulado.php?nid=1951\&tabela=leis\&nv ersao=\&so_miolo=. Acesso em: 22 abr. 2021.

RÉPUBLIQUE FRANÇAISE. Huissier de justice. Disponível em: https://www.servicepublic.fr/particuliers/vosdroits/F2158. Acesso em: 20 abr. 2021.

RÉPUBLIQUE FRANÇAISE. Officier public ministériel. Disponível em: https://www.service-public.fr/particuliers/glossaire/R53971. Acesso em: 20 abr. 2021.

RODRIGUES, Marco Antonio; RANGEL, Rafael Calmon. O procedimento extrajudicial pré-executivo lusitano (PEPEX): algumas lições para o sistema brasileiro. Revista de Processo, v. 282, São Paulo, p. 455-471, ago. 2018.

SANDER, Frank E. A. Varieties of Dispute Processing. Eagan: West Publishing Company, 1976.

SOUZA, Miguel Teixeira de. A reforma da acção executiva. Lisboa: LEX, 2004.

STEDMAN, Barbara Epstein. Multi-option justice at the Middlesex Multi-Door Courthouse. In: SMITH, Roger (edit.). Achieving Civil Justice: Appropriate dispute resolution for the 1990s. London: Legal Action Group, 1996.

VAN RHEE, Cornelis Hendrik, UZELAC, Alan. Enforcement and Enforceability Tradition and Reform. Intersentia: Cambridge, 2010. 